\title{
Assessing the Learning Level of Students through Bloom's Taxonomy in Higher Education in Punjab
}

\author{
Haq Nawaz Anwar \\ Professor, Department of Sociology, G.C University Faisalabad, Pakistan \\ Malik Muhammad Sohail \\ M. Phil Scholar, G.C University Faisalabad, Pakistan
}

\section{Doi:10.5901/jesr.2014.v4n3p83}

\begin{abstract}
Education is essential component for development and growth in any society. Evaluation is very important factor in education. An educational professional must be able to effectively evaluate and assess the students'academic development and knowledge of the subjects being taught. The present study focuses on assessment methods in learning. Bloom's taxonomy was used as assessment tool to gauge students' level of learning in three public sector universities of Punjab, Pakistan. A total of 300 respondents were chosen as sample for this study. Cognitive Domain of Bloom's taxonomy was applied to assess level of learning.
\end{abstract}

\section{Introduction}

In education one of the most burning problems is to help students develop effective methods for learning. The educational institutions demands that the students spend many hours, many days, and many years in learning the subject matter, skills, and attitudes essential for useful living in a civilized community and for active citizenship in a democracy (Cohen, 1972).Learning is the attainment of new behavior patterns, or the strengthening or weakening of old behavior patterns, as the result of practice. Learning includes a wide variety of changes in behavior. The changes may be readily detected in the overt behavior of the individual or they may be changes in his reserve of ideas. Motives or drives are basic to the learning process. If we are to learn, we must first have some goals and then come across some blocks that stop us from achieving that goal. If we encounter no block-no difficulty of any kind-the chances are that we have already learned the behavior necessary to reach the goal or that we will not learn it until our goal becomes more attractive and more demanding (Srivastava, 2006).Learning is a complex concept and activity. Most teachers and pupils would recognize the importance of the social and emotional elements of learning, in addition to cognitive aspects of learning, thinking and problem solving (Hewitt, 2008).Bloom's Taxonomy was initially published in 1956 under the leadership of American academic and educational expert Dr. Benjamin S Bloom. Bloom's Taxonomy model is in three parts; (1) Cognitive domain (intellectual capability, i.e., knowledge, or 'think'), (2) Affective domain (feelings, emotions and behavior, i.e., attitude, or 'feel') and (3) Psychomotor domain (manual and physical skills, i.e., skills, or 'do'). Bloomand his colleagues' initial attention was focused on the 'Cognitive Domain', which was the first published part of Bloom's Taxonomy, The Cognitive Domain' (Bloom, Engelhart, Furst, Hill, Krathwohl, 1956) \& (Chapman, 2006).

\section{Bloom's Taxonomy - Cognitive Domain - (Intellect - Knowledge - 'Think')}

Bloom's Taxonomy 1956 Cognitive Domain is as follows. An adjusted model was produced by Anderson and Krathwhol in 2001 in which the levels five and six (synthesis and evaluation) were inverted (Atherton, 2010).Cognitive domain deals with elements like Knowledge; Remembering previously learned information, memorize, Comprehension; Grasping the meaning of information, interpret, Application; Applying knowledge to actual situation, putting theory into practice, Analysis; Breaking down objects or ideas into simpler parts and seeing how the parts relate and are organized, interpret elements of structure, Synthesis; Rearranging component ideas into a new whole, develop creative thinking, Evaluation; Make judgments about value of ideas or materials, assess effectiveness. 


\section{Research Methodology}

The universe of this research comprised of the male and female students from different departments of three selected universities situated in Punjab.Three universities were selected from all over the Punjab through multistage sampling method. A sample of 300 students including males and females was interviewed. The survey method was used as the main data-gathering tool for this research. The questionnaire was divided into different sections according to variables.

\section{Results and Discussion}

\subsection{Demographic Variables}

Demographic questions are essential in survey research probably. A summary of demographic variables is presented in the following table.

Table 1: Demographic Characteristics

\begin{tabular}{|c|c|c|}
\hline Sex Composition & Frequency $(f)$ & Percentage \\
\hline Male & 163 & 54.3 \\
\hline Female & 137 & 45.7 \\
\hline \multicolumn{3}{|l|}{ Type of Schooling } \\
\hline Private school & 150 & 50.0 \\
\hline Govt. school & 150 & 50.0 \\
\hline \multicolumn{3}{|l|}{ Age Categories (years) } \\
\hline $18-20$ & 84 & 28.0 \\
\hline $21-23$ & 197 & 65.7 \\
\hline 24 and above & 19 & 6.3 \\
\hline \multicolumn{3}{|l|}{ Level of Study } \\
\hline Under-graduation & 165 & 55.0 \\
\hline Post-graduation & 107 & 35.7 \\
\hline M. Phil & 24 & 8.0 \\
\hline Ph. D & 4 & 1.3 \\
\hline \multicolumn{3}{|l|}{ Area of Residence } \\
\hline Elite class colony & 10 & 3.3 \\
\hline Upper middle class area & 85 & 28.3 \\
\hline Middle class area & 195 & 65.0 \\
\hline Lower class area & 10 & 3.3 \\
\hline \multicolumn{3}{|c|}{ Total Household Monthly Income (Rs.) } \\
\hline Up to 10 thousand & 23 & 7.7 \\
\hline 10 to 20 thousands & 44 & 14.7 \\
\hline 21 to 30 thousands & 80 & 26.7 \\
\hline 31 to 40 thousands & 61 & 20.3 \\
\hline More than 40 thousands & 92 & 30.7 \\
\hline \multicolumn{3}{|l|}{ Father's Occupation } \\
\hline Business man & 92 & 30.7 \\
\hline Professional & 95 & 31.7 \\
\hline Manager & 17 & 5.7 \\
\hline Manual labor & 23 & 7.7 \\
\hline Agriculture & 73 & 24.3 \\
\hline \multicolumn{3}{|c|}{ Father's Educational Level } \\
\hline Under matric & 49 & 16.3 \\
\hline Matric & 64 & 21.3 \\
\hline FA & 51 & 17.0 \\
\hline $\mathrm{BA}$ & 59 & 19.7 \\
\hline Master & 62 & 20.7 \\
\hline Above & 15 & 5.0 \\
\hline
\end{tabular}




\begin{tabular}{|l|c|c|}
\hline Mother's Educational Level & & \\
\hline Under matric & 105 & 35.0 \\
\hline Matric & 71 & 23.7 \\
\hline FA & 41 & 13.7 \\
\hline BA & 51 & 17.0 \\
\hline Master & 27 & 9.0 \\
\hline Above Total & 5 & 1.7 \\
\hline \multicolumn{2}{|c|}{} & 100.0 \\
\hline
\end{tabular}

Socio-demographic characteristics of students and their parents are important when studying classroom socioenvironmental characteristics and educational outcomes. Some demographic features form a specific status of student i.e., sex composition, age composition, type of school andarea of residence. Educational research consistently reports lower achievement among students of lower socioeconomic status (Stockard\& Mayberry, 1992).In present study 54.3\% respondents were males and $45.7 \%$ were females. $50.0 \%$ respondents studied in private schools, while $50.0 \%$ went to government schools. These results reflect that private schooling has increased in country in the last two decades. There are many factors that may be conducive to learning or hamper learning on other side. It evidently shows that $65.7 \%$ were in the age group of 21 to 23 years. More than one-fourth i.e., $28.0 \%$ were in the age group of 18 to 20 years. A minor part that is $6.3 \%$ was in the age group of 24 and above. Previous studies suggest that socio-economic status influences students' academic careers (Campbell\& Alexander, 1965).Lower income and lack of facilities can result in long-term problems for individuals with learning disabilities. Above table describes the household monthly income of students. Table shows that $7.7 \%$ respondents' household monthly income is up to 10 thousand rupees. $14.7 \%$ respondents are those who have household monthly income 10 to 20 thousand rupees. A majority that is $26.7 \%$ respondents' household monthly income was 21 to 30 thousand rupees.

\subsection{Learning Level of Student}

Learning is frequently defined as a change in behavior which is revealed by people implementing knowledge, skills, or practices derived from education. Basically, from an educator's perspective, learning involves helping people along the learning process, and learning includes all of the things that we do to make it happen. There are numerous approaches, tools and techniques to assess the level of learning of students. In next section two approaches of learning have been practiced to evaluate students' learning level.

Table 2: Judgment of Respondents about Learning under the umbrella of Blooms Taxonomy

\begin{tabular}{|c|c|c|c|c|c|c|c|c|}
\hline \multirow[t]{2}{*}{ Statements } & \multicolumn{2}{|c|}{ Agree } & \multicolumn{2}{|c|}{$\begin{array}{l}\text { Neither agree nor } \\
\text { disagree }\end{array}$} & \multicolumn{2}{|c|}{ Disagree } & \multicolumn{2}{|c|}{ Total } \\
\hline & $f$ & $\%$ & $f$ & $\%$ & $F$ & $\%$ & $f$ & $\%$ \\
\hline Can you remember previously learned information? & 194 & 64.7 & 78 & 26.0 & 28 & 9.3 & 300 & 100.0 \\
\hline Do you Grasp the meaning of information? & 196 & 65.3 & 76 & 25.3 & 28 & 9.3 & 300 & 100.0 \\
\hline Can you Apply knowledge to actual situation? & 198 & 66.0 & 63 & 21.0 & 39 & 13.0 & 300 & 100.0 \\
\hline $\begin{array}{l}\text { Are you able to Break down objects or ideas into simpler parts and see } \\
\text { how the parts relate and are organized? }\end{array}$ & 180 & 60.0 & 96 & 32.0 & 24 & 8.0 & 300 & 100.0 \\
\hline Are you able to Rearrange component ideas into a new whole? & 191 & 63.7 & 82 & 27.3 & 27 & 9.0 & 300 & 100.0 \\
\hline $\begin{array}{l}\text { Can you Make judgments about value of ideas or materials in a critical } \\
\text { situation? }\end{array}$ & 180 & 60.0 & 87 & 29.0 & 33 & 11.0 & 300 & 100.0 \\
\hline
\end{tabular}

The section refers to the assessment of students' learning by using "blooms taxonomy" as a tool. Bloom's Taxonomy is a classification of learning objectives within education proposed in 1956 by a committee of educators chaired by Benjamin Bloom who also edited the first volume of the standard text, Taxonomy of educational objectives: the classification of educational goals.A majority of $64.7 \%$ respondents were agreed that they can remember previously learned information. $26.0 \%$ were neither agreed nor disagreed. $9.3 \%$ were disagreed. $65.3 \%$ respondents were agreed that they grasp the meaning of information while $25.3 \%$ were neither agreed nor disagreed. Only $9.3 \%$ were disagreed.66.0\% respondents were agreed that they apply knowledge to actual situation whilst $21.0 \%$ were neither agreed nor disagreed. $13.0 \%$ were disagreeing. $60.0 \%$ respondents were agreed that they are able to break down objects or ideas into simpler parts. $32.0 \%$ 
were neither agreed nor disagree while $8.0 \%$ were disagreeing.63.7\% respondents were agreed that they are able to rearrange component ideas into a new whole. $27.3 \%$ were neither agreed nor disagree. $9.0 \%$ were disagreeing. $60.0 \%$ respondents were agreed that they can make judgments about value of ideas or materials in a critical situation. $29.0 \%$ were neither agreed nor disagree. $11.0 \%$ were disagreeing.

Table 3: Judgment of Respondents about Learning under the umbrella of Blooms Taxonomy (Mean \& Standard Deviation)

\begin{tabular}{|l|c|c|c|}
\hline \multicolumn{1}{|c|}{ Statements } & Mean & Std.Dev. & Rank \\
\hline Do you Grasp the meaning of information? & 2.56 & .71 & 1 \\
\hline Can you remember previously learned information? & 2.55 & .69 & 2 \\
\hline Are you able to Rearrange component ideas into a new whole? & 2.55 & .69 & 3 \\
\hline Can you Apply knowledge to actual situation? & 2.53 & .66 & 4 \\
\hline $\begin{array}{l}\text { Are you able to Break down objects or ideas into simpler parts and see how the parts } \\
\text { relate and are organized? }\end{array}$ & 2.52 & .65 & 5 \\
\hline Can you Make judgments about value of ideas or materials in a critical situation? & 2.49 & .62 & 6 \\
\hline
\end{tabular}

2.56 is mean value for the question asked "Do you grasp the meaning of information". The second question was "Can you remember previously learned information" that holds 2.55 mean value. Similar mean value was contained by the statement "Are you able to rearrange component ideas into a new whole". 2.53 mean value can be viewed for statement "Can you Apply knowledge to actual situation". The statement "Are you able to break down objects or ideas into simpler parts and see how the parts relate and are organized" grasps 2.52 mean value. The last statement "Can you make judgments about value of ideas or materials in a critical situation" has 2.49 mean.

\subsection{Bi-variate Analysis}

Table 4: Association between sex composition, age, schooling and socio-economic status and Student's learning in Classrooms

\begin{tabular}{|l|c|c|c|}
\hline Variables & Chi-square value & Gamma value & Pearson Correlation \\
\hline Sex composition & $9.72^{\star}$ & $-.187^{\star}$ & $-.118^{\star}$ \\
\hline Age & $14.58^{\star \star}$ & $-.117^{\mathrm{NS}}$ & $.015^{\mathrm{NS}}$ \\
\hline Schooling & $7.59^{\star}$ & $-.271^{\star \star}$ & $-.161^{\star \star}$ \\
\hline Socio-economic status & $10.59^{\star}$ & $.214^{\star \star}$ & $.140^{\star}$ \\
\hline
\end{tabular}

A Dependent Variable: Students' learning in classroom; * Significant at 5\% level of significance; ** Significant at $1 \%$ level of significance; NS = Non-significant at $5 \%$ level of significance

Gender is an important predictor of performance in higher education (Buchmann\&DiPrete, 2006). Families often make educational investment decisions based on a cost-benefit analysis of increased utility (Becker, 1991). The findings of this study reveal that male students are better in learning in classroom as compared to female students. The age has no impact on students' learning in classroom. Private schooling found to be better for students' learning as compared to government schooling. Socio-economic status was positively associated with learning.

\section{Conclusion}

The above study concludes that majority of students are able to pick main ideas delivered by teacher during lectures. They retain what is presented to them. The level of students' learning also has some flaws. The findings of this study reveal that male students are better in learning in classroom as compared to female students. The age has no impact on students' learning in classroom. Private schooling found to be better for students' learning as compared to government schooling. Socio-economic status was positively associated with learning. 


\section{References}

Atherton, J. (2010, February). Learning and Teaching; Bloom's taxonomy.Retrieved August 13, 2012, from www. learningandteaching.info.

Becker, G. S. (1991). A treatise on the family. Cambridge, MA: Harvard University Press.

Buchmann, C., \& DiPrete, T. (2006). The growing female advantage in college completion: The role of family background and academic achievement. American Sociological Review, 71, 515-541.

Campbell, E. Q., \& Alexander, C. N. (1965).Structural effects and interpersonal relationships.American Journal of Sociology, 71,284289.

Chapman, A. (2006). Retrieved August 13, 2013, from www.businessballs.com: http://www.businessballs.com/bloomstaxonomyo flearningdomains.htm.

Cohen, e. g. (1972).sociology and the classroom: setting the conditions for teacher-student interaction.Chicago: American educational research institution.

Corwin.Barker, R. G., \& Gump, P. (1964).Big school, small school.Stanford, CA:Stanford University Press.

Hewitt, D. (2008). Understanding Effective Learning. Buckingham: Open University Press.

Srivastava, N. (2006). Educational Psychology.Global Media.

Stockard, J., \& Mayberry, M. (1992).Effective educational environments.Newbury Park, CA: 
